\title{
Activation of mRNA translation by phage protein and low temperature: the case of Lactococcus lactis abortive infection system AbiD I
}

\author{
Elena Bidnenko*, Alain Chopin, S Dusko Ehrlich and Marie- \\ Christine Chopin
}

Address: Laboratoire de Génétique Microbienne, INRA, 78352 Jouy-en-Josas, France

Email: Elena Bidnenko* - elena.bidnenko@jouy.inra.fr; Alain Chopin - alain.chopin@jouy.inra.fr; S Dusko Ehrlich - dusko.ehrlich@jouy.inra.fr; Marie-Christine Chopin - marie-christine.chopin@jouy.inra.fr

* Corresponding author

Published: 27 January 2009

BMC Molecular Biology 2009, 10:4 doi:10.1186/147I-2199-10-4

This article is available from: http://www.biomedcentral.com/I47I-2/99//0/4

(C) 2009 Bidnenko et al; licensee BioMed Central Ltd.

This is an Open Access article distributed under the terms of the Creative Commons Attribution License (http://creativecommons.org/licenses/by/2.0), which permits unrestricted use, distribution, and reproduction in any medium, provided the original work is properly cited.
Received: 20 April 2008

Accepted: 27 January 2009

\begin{abstract}
Background: Abortive infection (Abi) mechanisms comprise numerous strategies developed by bacteria to avoid being killed by bacteriophage (phage). Escherichia coli Abis are considered as mediators of programmed cell death, which is induced by infecting phage. Abis were also proposed to be stress response elements, but no environmental activation signals have yet been identified. Abis are widespread in Lactococcus lactis, but regulation of their expression remains an open question. We previously showed that development of AbiDI abortive infection against phage bIL66 depends on orfl, which is expressed in mid-infection. However, molecular basis for this activation remains unclear.
\end{abstract}

Results: In non-infected AbiDI+ cells, specific abiDl mRNA is unstable and present in low amounts. It does not increase during abortive infection of sensitive phage. Protein synthesis directed by the $a b i D /$ translation initiation region is also inefficient. The presence of the phage orfl gene, but not its mutant AbiD IR allele, strongly increases abiD / translation efficiency. Interestingly, cell growth at low temperature also activates translation of $a b i D /$ mRNA and consequently the AbiDI phenotype, and occurs independently of phage infection. There is no synergism between the two abiDI inducers. Purified Orfl protein binds mRNAs containing a secondary structure motif, identified within the translation initiation regions of abiD/, the mid-infection phage blL66 Moperon, and the L. lactis osmC gene.

Conclusion: Expression of the abiD I gene and consequently AbiDI phenotype is specifically translationally activated by the phage Orfl protein. The loss of ability to activate translation of $a b i D /$ mRNA determines the molecular basis for phage resistance to AbiDI. We show for the first time that temperature downshift also activates abortive infection by activation of abiD/ mRNA translation. 


\section{Background}

Bacteria have developed diverse mechanisms to avoid killing by bacteriophages (phages), which are abundant in the environment. One group of mechanisms, usually denoted as phage exclusion, or abortive infection (Abi), is characterized by a normal start of the infection process, followed by an interruption of intracellular phage development, leading to the release of few or no progeny particles and the death of the infected cell. As a consequence, further propagation of phages is prevented and the bacterial population survives.

Abi mechanisms are widespread in bacteria [1-5], but have been mainly reported in Escherichia coli and Lactococcus lactis [6-9]. The best studied mechanisms, F-factor mediated T7 exclusion, lambda Rex, Prr and Lit, all operate in E. coli $[6,10,7]$. Despite their diverse modes of action, all these systems involve a cellular protein whose function is activated or inhibited following phage infection [11-17]. Thus, Abis are considered as "altruistic death modules" that favour cell population survival following phage infection. However, recent findings suggest that Abi mechanisms might have other functions besides mediating phage resistance. The latent PrrC nuclease was shown to be induced by normal cell constituents such as pyrimidine nucleotides, which suggests that this enzyme could play roles in addition to warding off phage T4 infection [13]. PifA is suggested to be a sensor for certain environmental changes [12]. Similarly, the Rex operon could prevent programmed cell death in starved $E$. coli cells by inhibiting the ClpP family of proteases or cause a stationary phase-like response $[18,19]$. However, except for phage encoded proteins, no environmental signals responsible for Abi activation have been identified.

Lactococcal Abi systems have been shown to interfere with different steps of phage development, including DNA replication, maturation and packaging, transcription, capsid production and lysis of infected cells [20-22]. However, the molecular basis of these events, and the regulation of Abi systems are poorly understood. Unlike E. coli mechanisms, phage-dependent activation of Abis has not yet been demonstrated in lactococci. No alteration in transcriptional levels was observed for abiA, abiB, abiD1 and $a b i G$ genes examined for induction by respective phages [23-25]. A slight increase of specific transcript after phage infection was demonstrated only for abiP gene [26]. However, some experimental data suggests post-transcriptional regulation of expression and/or function of lactococcal abis. AbiR requires an associated methylase to protect the host from its own action [21]. Cloning of intact $a b i G$ was shown to be lethal for heterologous $E$. coli cells [25]. Therefore, direct or indirect induction of latent Abi activity by an infecting phage or/and other factors in L. lactis is quite probable [20].
The AbiD1 abortive infection mechanism is encoded by a single gene, abiD1, of plasmid pIL105 $[27,24]$. Over-production of AbiD1 was shown to have bacteriostatic effect in L. lactis cells suggesting a tight control of abiD1 expression in its natural genetic background [24]. Expression of abiD1 was proposed to be induced following phage infection $[28,20]$.

Among dozens of AbiD1 sensitive phages, only the small isometric-headed phage bIL66 is able to form spontaneous AbiD1-resistant mutants. These mutants have been used to study the AbiD1 mode of action $[28,29]$. Phage sensitivity to AbiD1 is determined by the $M$ operon, which is expressed in mid-infection, and contains four orfs, denoted orf1 to orf4. The orf3 product is essential for phage development and its activity decreases in the presence of AbiD1 [29]. We showed that Orf3 is a structurespecific endonuclease homologous to the E. coli RuvC resolvase [30], which appears to be crucial for phage DNA replication and maturation prior to packaging $[31,32]$.

All bIL66 AbiD1 ${ }^{\mathrm{R}}$ mutants contain a point mutation within orf1, the first gene of the M-operon, coding for a 42 amino acid peptide. One AbiD $1^{\mathrm{R}}$ mutant has an amino acid change (Orf1M1) and others have a stop codon within the first 15 residues (Orf1M2). The N-terminal region of Orf1 plays a key role in phage sensitivity to AbiD1. Phages deleted for the corresponding orf1 region are viable and resistant to AbiD1. However, the C-terminal region downstream of the Met 15 codon is essential for phage viability and cannot be deleted from the phage genome [28]. Expression of orf1 in trans increases AbiD1 efficiency and prevents growth of $\mathrm{AbiD} 1{ }^{\mathrm{R}}$ phage mutants. Orf1 has no known homologs in the sequence databases. We proposed that, similar to $E$. coli exclusion systems that are activated by phage-encoded proteins, Orf1 activates latent AbiD1 during phage infection, while mutant Orf1 proteins from $A b i D 1^{R}$ phages fail to do so [28]. The molecular mechanism leading to abiD1 activation remains to be clarified.

To gain insight into the mechanism of abiD1 activation and to identify potential abiD1 activation signals, we studied the regulation of abiD1 expression. Here we show that phage-encoded Orf1 protein specifically activates expression of abiD1 at the level of abiD1 mRNA translation. Moreover, expression of AbiD1 is activated at the translational level independently of phage infection during growth of cells at low temperature.

\section{Methods \\ Bacterial strains, phages and media}

L. lactis subsp. lactis IL1403 and derivatives were grown at $30^{\circ} \mathrm{C}$ in $\mathrm{M} 17$ medium supplemented with $0.5 \%$ glucose. E. coli TG1, BL21 (DE3) (Stratagene). Bacillus subtilis 168 
strains were grown at $37^{\circ} \mathrm{C}$ in $\mathrm{LB}$ medium. When needed, ampicillin (Ap), $100 \mu \mathrm{g} \mathrm{ml}^{-1}$; erythromycin (Em) $(200 \mu \mathrm{g}$ $\mathrm{ml}^{-1}$ for E. coli, $5 \mu \mathrm{g} \mathrm{ml}^{-1}$ for L. lactis and $0.5 \mu \mathrm{g} \mathrm{ml}^{-1}$ for $B$. subtilis), and chloramphenicol $(\mathrm{Cm})\left(40 \mu \mathrm{g} \mathrm{ml}^{-1}\right.$ for RNA extraction from L. lactis and $3 \mu \mathrm{g} \mathrm{ml}^{-1}$ for B. subtilis) were added to the culture medium. Glucose was added to $0.5 \%$, xylose was added to $1 \%$. E. coli TG1 strain, B. subtilis 168 strain, L. lactis strains IL1403, IL1403 (pIL105) [27], phage bIL66 and its AbiD1 ${ }^{\mathrm{R}}$ mutants bIL66M1 and bIL66M2 [29] were from our laboratory collection. Phages were enumerated as described [24].

\section{Molecular cloning and DNA sequence analysis}

Procedures for DNA manipulation, cloning and transformation of E. coli were essentially as described [33]. Electrotransformation of $L$. lactis was carried out as described [34]. Polymerase chain reaction (PCR) was performed using the Gene AMP PCR System 9700 (Applied Biosystems) and ExTaq (Takara Biomedicals) essentially as described by the supplier. Nucleotide sequencing was performed on PCR products by using appropriate primers, Taq polymerase (Applied Biosystems) and fluorescent dideoxyribonucleotides on a 377A DNA sequencer (Applied Biosystems).

\section{mRNA extraction and analysis}

Total RNA was extracted using High Pure RNA Isolation Kit (Roche) according to manufacturer's manual. Northern Blot experiments were performed using a nylon Hybond XL membrane (Amersham Pharmacia Biotech) and oligonucleotide $n^{\circ} 1$ as a probe (Additional file 1: Oligonucleotides used in this study). Oligonucleotides used for hybridization were labeled at the 5 '-end with $\left[\gamma_{-}{ }^{32} \mathrm{P}\right]$ ATP using T4 polynucleotide kinase (New England BioLabs) as described by the supplier. Northern dot-blot analysis was performed using Bio-Dot Microfiltration Apparatus (BioRad) according to instruction manual. For this, $20 \mu \mathrm{g}$, and successive dilutions, of RNA sample extracted from cells grown at $30^{\circ} \mathrm{C}$ and $18^{\circ} \mathrm{C}$ were treated with $50 \mathrm{U}$ of RNase-free DNase I (Roche) for $20 \mathrm{~min}$ at $37^{\circ} \mathrm{C}$ and used for hybridization with abiD1-specific or luxAB-specific probe. The abiD1 DNA fragment was amplified using oligonucleotides $\mathrm{n}^{\circ} 2$ and $\mathrm{n}^{\circ} 3$. The $\operatorname{lux} A B$ DNA fragment was amplified using oligonucleotides $n^{\circ} 4$ and $\mathrm{n}^{\circ} 5$. RNA was quantified with a PhosphorImager using ImageQuant (version 5.2; Molecular Dynamics) software. The quantitative reverse transcription-PCR was used to quantify mRNAs. Twenty $\mu \mathrm{g}$ RNA, extracted from 2-ml cultures, were treated with $50 \mathrm{U}$ of RNase-free DNase I (Roche) for $20 \mathrm{~min}$ at $37^{\circ} \mathrm{C}$. cDNAs were then synthesized using the reverse transcriptase reaction, using the CyScribe cDNA postlabelling kit (Amersham) with some modifications: RNA samples were incubated for $15 \mathrm{~h}$ at $42^{\circ} \mathrm{C}$ in a $20-\mu \mathrm{l}$ reaction containing random nonamer primers, reverse transcriptase buffer, dithiothreitol,
dNTPs, and $200 \mathrm{U}$ of Superscript III reverse transcriptase (Invitrogen). Gene sequences were amplified from cDNA dilutions by PCR and quantified using an ABI Prism 7000 (Applied Biosystems). For the abiD1 transcript, cDNA was amplified using oligonucleotides $\mathrm{n}^{\circ} 6$ and $\mathrm{n}^{\circ} 7$. For the $\mathrm{lux}$ transcript, cDNA amplification was carried out using oligonucleotides $n^{\circ} 8$ and $n^{\circ} 9$. Results were normalized using the L. lactis tuf gene, coding for the elongation factor $\mathrm{TU}$, as control. tuf cDNA was amplified using oligonucleotides $n^{\circ} 10$ and $n^{\circ} 11$. Changes in relative amounts of transcript mRNA normalized to tuf were determined using the relative $\mathrm{C}_{\mathrm{T}}$ method $[35,36]$.

\section{Plasmid construction}

Fusions between abiD1 translation initiation regions (TIRs) and $l u x A B$ genes were constructed by cloning different fragments of abiD1 TIR between the BamHI and EcoRI sites of the pBluescript SKII plasmid vector (Stratagene). Then, luxAB genes were inserted at the ATG start position of TIRs by cloning the luciferase plasmid fusion vector pJIM1715 [37] at the NdeI site. Finally, pBluescript SKII DNA was deleted from the resulting plasmids by EcoRI digestion and self-ligation. Different abiD1 TIR DNA fragments were amplified using pIL105 plasmid DNA, oligonucleotide $\mathrm{n}^{\circ} 13$ carrying $\mathrm{Bam} \mathrm{HI}$ and $\mathrm{NdeI}$ sites, and one of the following oligonucleotides: $\mathrm{n}^{\circ} 14$, carrying an EcoRI site (fragment I), $\mathrm{n}^{\circ} 15$ carrying an EcoRI site (fragment II), $\mathrm{n}^{\circ} 16$ carrying an EcoRI site (fragment III). The abiD1 TIR IV fragment was amplified using fragment II cloned in pBluescript SKII plasmid vector as a template, oligonucleotides $\mathrm{n}^{\circ} 17$, carrying an EcoRI site and $\mathrm{n}^{\circ} 18$, carrying a ClaI site. Resulting plasmids were designated pIL5014 (abiD1 TIR I), pIL5015 (abiD1 TIR II), pIL5016 (abiD1 TIR III) and pIL5026 (abiD1 TIR IV). The orf1 gene from phage bIL66 and bIL66M1 or bIL66M2 mutants was inserted upstream of the different abiD1 TIR:luxAB fusions. For this, PCR fragments corresponding to the different orf1 genes were first cloned in the pBluescript SKII plasmid vector. Fragments were recovered by digestion with EcoRI, and then cloned at the EcoRI site of plasmids pIL5014 and pIL5015. Oligonucleotides $n^{\circ} 19$ and $n^{\circ} 20$ were used for the PCR amplification. aldB:luxAB fusion plasmid pIL5032 was constructed in the same manner using oligonucleotides $\mathrm{n}^{\circ} 21$ and $\mathrm{n}^{\circ} 22$, carrying EcoRI and BamHI $\left(\mathrm{n}^{\circ} 21\right)$, and NdeI sites $\left(\mathrm{n}^{\circ} 22\right)$. To construct plasmid pIL5033, the orf1 gene from phage bIL66 was inserted at the EcoRI site of pIL5032. To integrate the orf1 gene from phage bIL66 or bIL66M2 into the $B$. subtilis chromosome, both genes were initially cloned into PacI, BamHI sites of plasmid pSWEET [38]. To do this, orf1 or orf1M1 PCR fragments were amplified with oligonucleotides $n^{\circ} 23$ carrying a PacI site and $\mathrm{n}^{\circ} 24$ carrying a BamHI site. Cloning was performed in E. coli strain TG1. The resulting plasmids were targeted to amyE of B. subtilis via double recombination as linear DNA, using PstI-digested plasmid. To 
construct plasmid pIL5033, the rbfA gene from L. lactis IL1403 was amplified with oligonucleotide $\mathrm{n}^{\circ} 25$, carrying a SalI site, and $n^{\circ} 26$, carrying a PstI site, and ligated to SalI, PstI-digested plasmid pGKV259 [39].

\section{Luciferase assay}

L. lactis IL1403 cells transformed with various $l u x A B$ constructs were grown to an optical density at $600 \mathrm{~nm}$ $\left(\mathrm{OD}_{600}\right)$ of 0.4 at either $30^{\circ} \mathrm{C}$ or $18^{\circ} \mathrm{C}$ in $\mathrm{M} 17$ medium. Experimental conditions for oxidative stress and acid $\mathrm{pH}$ used for the luciferase assay were mainly as described $[40,41]$. Exponentially growing L. lactis IL 1403 cells were incubated with $1 \mathrm{mM} \mathrm{H}_{2} \mathrm{O}_{2}$ to generate oxidative stress conditions. The range of acid $\mathrm{pH}$ tested was 4.5, 4.2 and 4.0. B. subtilis 168 cells were grown to an $\mathrm{OD}_{600}$ of 0.1 at $30^{\circ} \mathrm{C}$ in $\mathrm{LB}$ medium in the presence of glucose, washed in $\mathrm{LB}$ and grown to an $\mathrm{OD}_{600}$ of 0.4 at $30^{\circ} \mathrm{C}$ in $\mathrm{LB}$ medium in the presence of xylose. To measure luciferase activity, 1 $\mathrm{ml}$ of culture was mixed with $5 \mu \mathrm{l}$ of nonylaldehyde (Acros Organics), and the light emission was measured immediately in a Lumat LB9501 luminometer (Berthold).

\section{Western blotting}

The $3 \times$ FLAG peptide sequence was cloned in the NdeI site of $a b i D 1$ TIR I:luxAB fusion plasmid pIL5014. The DNA fragment carrying the $3 \times$ FLAG peptide sequence was obtained by PCR amplification using p3 $\times$ FLAG-CMV-7 expression vector (Sigma-Aldrich) as a template and oligonucleotides $n^{\circ} 29$ and $n^{\circ} 30$ each carrying an NdeI site. The final construct was verified by sequencing. L. lactis cells carrying FLAG tagged abiD1 TIR I:luxAB fusion plasmid were grown to an $\mathrm{OD}_{600}$ of 0.4 at either $30^{\circ} \mathrm{C}$ or $18^{\circ} \mathrm{C}$ in M17 medium medium supplemented with $0.5 \%$ glucose. Cells were harvested, resuspended in $20 \mathrm{mM}$ Tris$\mathrm{HCl}, 10 \mathrm{mM}$ EDTA buffer, and lysed with $4 \mathrm{mg} / \mathrm{ml}$ lysozyme (Sigma-Aldrich) at $37^{\circ} \mathrm{C} 20 \mathrm{~min}$. Equal amounts $(20 \mathrm{mg})$ of proteins were separated on $8 \%$ SDS-PAGE gel electrophoresis and transferred to nylon Hybond-P membrane (Amersham Pharmacia Biotech). The membrane was blocked in Tris-buffered saline-0.1\% Tween 20 with $5 \%$ nonfat milk overnight and afterwards incubated sequentially with anti-FLAG tag mouse monoclonal antibody M2 (dilution 1:5000, Sigma -Aldrich) for $3 \mathrm{~h}$ and then alkaline phosphatase-conjugated goat anti-mouse IgG (dilution 1: 20000, Sigma-Aldrich) for $1 \mathrm{~h}$. Immunolabeled proteins were revealed using ECL Plus Western Blotting Detection System (Amersham Pharmacia Biotech) according to manufacturer's manual. Proteins were quantified with a PhosphorImager using the ImageQuant software.

\section{Production and purification of OrfI protein}

Protein expression and purification were performed using the IMPACT-SN system (New England Biolabs). The orf1 gene from phage bIL66 and bIL66M1 was cloned in the
pTYB11 expression vector. The DNA fragment carrying orf1 was obtained by PCR amplification using phage DNA as a template and oligonucleotides $\mathrm{n}^{\circ} 31$ (for Orf1 and Orf1M1 proteins) or $\mathrm{n}^{\circ} 32$ (for shortened Orf1M2 protein), both carrying a SapI site and $\mathrm{n}^{\circ} 33$, carrying an EcoRI site. Final constructs with $5^{\prime}$ intein-tagged orf1 genes were controlled by sequencing. Expression was performed in BL21 (DE3) E. coli cells at $17^{\circ} \mathrm{C}$ upon $15 \mathrm{~h}$ of induction with $0.6 \mathrm{mM}$ IPTG. Proteins extracted from the soluble fraction were further cleaved from the intein part and purified as recommended by the supplier. Purity of the final Orf1 protein preparation, evaluated using the Novex NuPage Pre-cast Gel System (Invitrogen), was > 90\%. The first eight $\mathrm{N}$-terminal amino acids (MTEEQLLF) were confirmed by MALDI-TOF (Applied Biosystems, Voyager DE super STR) to be identical to those deduced from the nucleotide sequence: The molecular mass of purified protein was $4850.43 \mathrm{Da}$ and corresponded to the theoretical molecular mass (4808.5 Da) of Orf1. Orf1M1 and Orf1 $1 \mathrm{M} 2$ proteins were purified in the same manner.

\section{RNA binding experiments}

abiD1, aldB, $\operatorname{trp} A$, osmC and M-operon RNA transcripts were prepared by run-off transcription of DNA templates with T7 RNA Polymerase transcription kit (Stratagene) in the presence of $\left[\alpha^{32} \mathrm{P}\right]$ rUTP $(800 \mathrm{Ci} / \mathrm{mmol}$; MP Biomedicals) according to manufacturer's manual. The different abiD1 DNA templates were obtained by PCR with the following oligonucleotides carrying the $\mathrm{T} 7$ promoter sequence: $\mathrm{n}^{\circ} 34$ (abiD1 transcript 1 and abiD1 transcript 5), n³5 (abiD1 transcript 2), n³6 (abiD1 transcript 3), $\mathrm{n}^{\circ} 37$ (abiD1 transcript 4), $\mathrm{n}^{\circ} 38$ (abiD1 transcript 6), $\mathrm{n}^{\circ} 39$ (abiD1 transcript 7), and used with oligonucleotides $\mathrm{n}^{\circ} 40$ (abiD1 transcripts 1 to 4$), \mathrm{n}^{\circ} 41$ (abiD1 transcript 5), $\mathrm{n}^{\circ} 42$ (abiD1 transcript 6) and $\mathrm{n}^{\circ} 43$ (abiD1 transcript 7). The DNA template for L. lactis IL1403 osmC RNA transcript was obtained by PCR with oligonucleotides: $n^{\circ} 44$ and $n^{\circ} 45$. The DNA template for L. lactis IL1403 aldB RNA transcript was obtained by PCR with oligonucleotides $n^{\circ} 46$ and $n^{\circ} 47$. The DNA template for L. lactis IL1403 trpA RNA transcript was obtained by PCR with oligonucleotides $n^{\circ} 48$ and $n^{\circ} 49$. The DNA template for bIL66 Moperon RNA transcript was obtained by PCR with oligonucleotides $n^{\circ} 50$ and $n^{\circ} 51$. The labelled RNA transcripts were purified by elution after separation on a non-denaturing $6 \%$ polyacrylamide gel at room temperature. Purified RNAs were resuspended in binding buffer $(10 \mathrm{mM}$ Tris $\mathrm{pH} 7.5,21 \mathrm{mM} \mathrm{KCl}, 1 \mathrm{mM}$ EDTA) and renatured by heating to $90^{\circ} \mathrm{C}$ for $1 \mathrm{~min}$ and chilling on ice for $2 \mathrm{~min}$. Binding reaction mixture, containing $10 \mathrm{ng}$ of the labeled transcript and various concentrations of purified Orf1 protein in $10 \mathrm{mM}$ Tris $\mathrm{pH} 7.5,21 \mathrm{mM} \mathrm{KCl}, 1 \mathrm{mM}$ EDTA, $1 \mathrm{mM}$ DTT, $5 \%$ glycerol, was incubated at $20^{\circ} \mathrm{C}$ for 30 min. Reactions were analyzed by electrophoresis in an $8 \%$ polyacrylamide gel at room temperature. 


\section{Results}

Transcriptional analysis of abiD I

To investigate the regulation of abiD1 gene expression, we first examined the abiD1 transcriptional unit. Sequence analysis of plasmid pIL105 (8506 bp, GenBank accession number $\underline{\text { AF116286) }}$ ) suggested that abiD1 might be transcribed in an operon with two downstream genes, coding for putative proteins of unknown function (Fig. 1A). A putative terminator sequence was identified $3.6 \mathrm{~kb}$ downstream of the determined transcription start [24]. However, previous attempts to visualize a full-length abiD1 transcript in Northern experiments were unsuccessful. The only visible transcript initiated at abiD1 promoter was 50 b long and was shown to stop at a terminator structure localized just upstream of the abiD1 gene [24] (Fig. 1B). Full-length abiD1 transcript was not revealed by Northern blot during abortive infection of IL1403 AbiD1+ cells with sensitive phage bIL66 [24]. Taking into account the pronounced abortive infection phenotype of IL1403 AbiD1+ cells, we hypothesized that during phage infection, full-length abiD1 transcript is present in functional amounts, but is probably highly unstable. To overcome this putative instability, we tried to visualize the fulllength abiD1 transcript by extracting RNA in the presence of chloramphenicol (Cm), which is known to stabilize bacterial mRNAs [42]. Two transcripts of $50 \mathrm{~b}$ and approximately $3.6 \mathrm{~kb}$ were revealed upon hybridization with primer 1 , the larger being much less abundant that the smaller (Fig. 1B). This 3.6-kb abiD1 transcript was not observed when RNA was extracted in the absence of $\mathrm{Cm}$, thus confirming low stability of abiD1 mRNA.

These results, together with those published earlier [24], indicate that the low amounts of the $3.6 \mathrm{~kb}$ mRNA transcript is most likely due to activity of the transcriptional terminator located upstream of the abiD1 gene. Read through across this terminator would be responsible for expression of abiD1. To investigate the possibility that phage-encoded protein(s) might increase synthesis of the full-length $3.6 \mathrm{~kb}$ abiD1 transcript either by an anti-termination mechanism or by stabilization of specific mRNA, we studied the synthesis of abiD1 mRNA after phage infection using quantitative reverse transcription PCR (QRTPCR) technique. The amount of the full-length abiD1 transcript was determined during one cycle of phage bIL66 multiplication, which takes approximately $40 \mathrm{~min}$. RNA samples were taken immediately before (time 0), in the middle (10 $\mathrm{min}$ ) and at the beginning of the late (20 min) steps of phage infection [43]. Our results show that the amount of full-length abiD1 transcript varied little during phage infection, and decreased slightly with time (Fig. 1C). Taken together, these results indicate that abiD1 is co-transcribed with two other genes of unknown function. The unstable full-length $3.6 \mathrm{~kb}$ abiD1 transcript results from read through across the transcriptional termi- nator and is present in low amounts, which do not increase during abortive infection with sensitive phage. This suggests that activation of the AbiD1 mechanism is not exerted at the level of synthesis or stabilization of abiD1 full-length mRNA.

\section{Analysis of abiD I expression at the translational level}

Expression of abiD1 was examined at the translational level. Translation initiation region (TIR) of abiD1 mRNA is 76 nucleotides long, and contains a transcriptional terminator, and a ribosome binding site (RBS) UUUGAAGG complementary to the L. lactis $16 \mathrm{~S}$ rRNA sequence with one mismatch (underlined) [44]. The RBS is preceded by a poly-U sequence, which is a part of the transcription terminator (Fig. 2A). Analysis of the abiD1 TIR sequence using MFOLD version 3.1 suggests the existence of a stemloop structure $(\Delta \mathrm{G}=-9.1 \mathrm{Kcal} /$ mole $)$ immediately downstream of the transcriptional terminator [45]. This structure could potentially sequester two elements known to positively control translation initiation efficiency, namely the RBS sequence and the poly-U sequence, which provides a binding site for ribosomal S1 protein [46]. Predicted by MFOLD mRNA secondary structure was crossvalidated by the programs RNAfold and Kinefold [47-49].

To test abiD1 translation efficiency we used the luxAB reporter gene from Vibrio fischeri [50]. Four DNA fragments corresponding to different parts of abiD1 TIR but missing the abiD1 promoter sequence were fused to the ATG start codon of the luxAB reporter gene that lacked its translational signals [[37], Methods]. Translation of luxAB is thus dependent on initiation signals carried on the cloned abiD1 TIR fragment. The constructs were transcribed from a constitutive plasmid promoter [37]. The four cloned fragments ended at the abiD1 ATG site and differed at their 5 ' ends (Fig. 2A). TIR I starts at the +1 transcription initiation point and would be able to form two stem-loop mRNA structures. TIR II contains a truncated transcriptional terminator stem-loop and an RBSsequestering stem-loop mRNA. TIR III contains a shortened poly-U sequence and would most probably not sequester the RBS. TIR IV contains only the abiD1 RBS sequence. Resulting plasmids were tested for their capacity to direct luciferase synthesis in L. lactis IL1403 cells. Luciferase activities detected with TIR I, II or IV were weak (Fig. 2B). Removal of the transcriptional terminator sequence (TIR II) has no positive effect on luciferase activity, confirming that it does not play a major role in regulating abiD1 expression. Luciferase activity detected with TIR III was 4.5 -fold higher, suggesting that sequestering of abiD1 RBS by secondary structure has a negative effect on translation efficiency. Nevertheless, the level of luciferase activity directed by abiD1 TIR III was relatively low: A control, the lactococcal aldB RBS cloned on plasmid vector pJIM1715, which reached $180 \pm 30 \times 10^{3}$ arbitrary light 

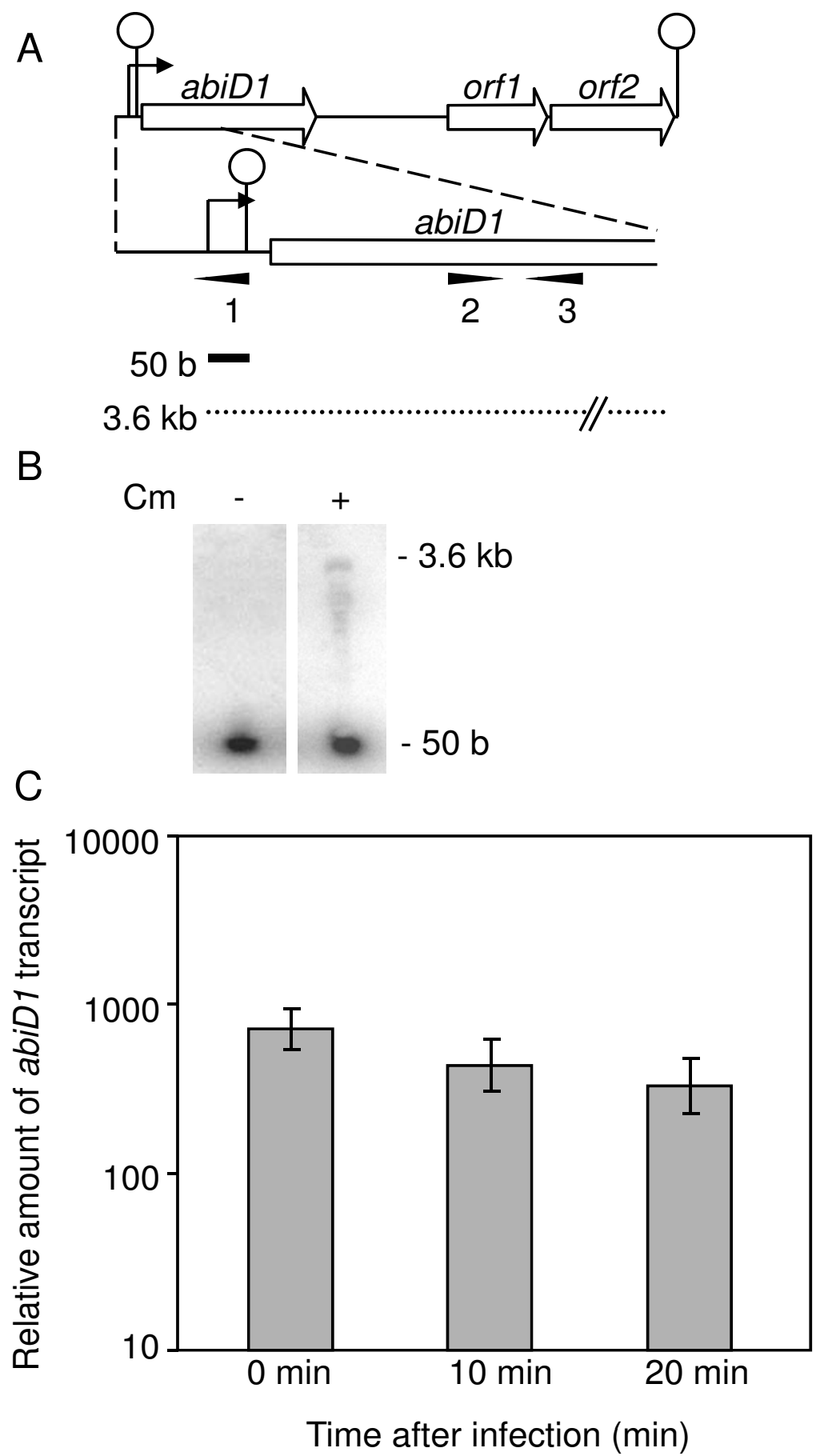

Figure I

Transcriptional analysis of the abiDI gene. (A) Schematic organization of the abiD I gene region. Bent arrows and circles denote promoter and terminator sequences, respectively. Position of oligonucleotides used for Northern hybridization (I) and quantitative RT-PCRs are indicated by tail-less arrows. Transcripts initiated at the abiD / promoter are shown by solid (50 b) and broken $(3.6 \mathrm{~kb})$ lines. (B) Northern hybridization results. RNA was extracted from ILI 403 AbiDI+ cells grown with or without $\mathrm{Cm}$. Hybridization was performed with oligonucleotide $\mathrm{n}^{\circ} \mathrm{I}$. (C) Quantitative RT-PCRs. abiD/ transcript was followed in ILI403 AbiDI+ cells. Samples were taken before (time 0), 10 and 20 min after infection with bIL66 phage. Amount of abiDI transcript was normalized to L. lactis tuf transcript level. Values shown are means of 9-I5 measurements, expressed in arbitrary units. 


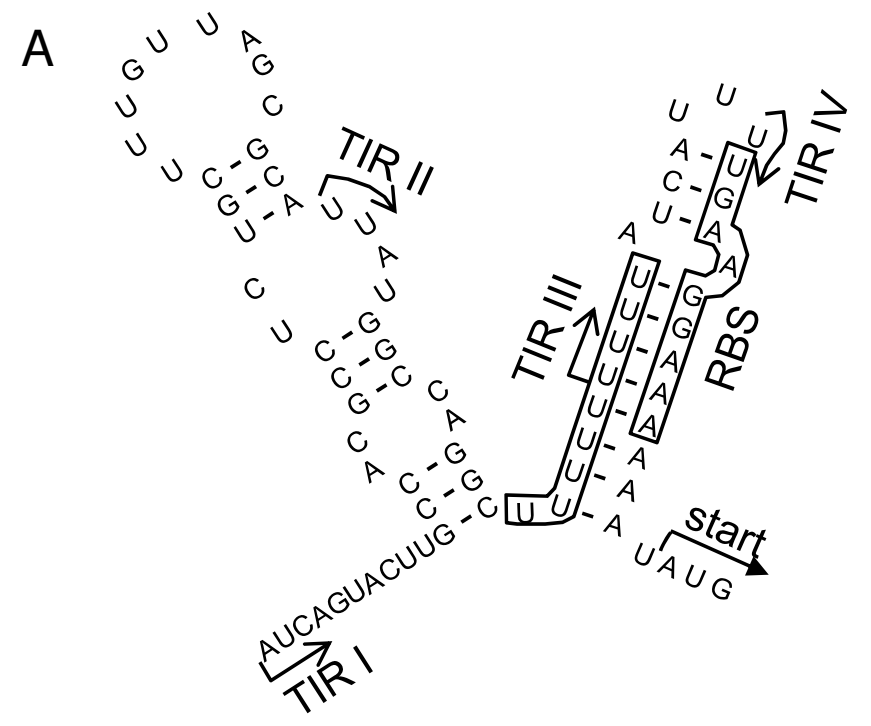

B

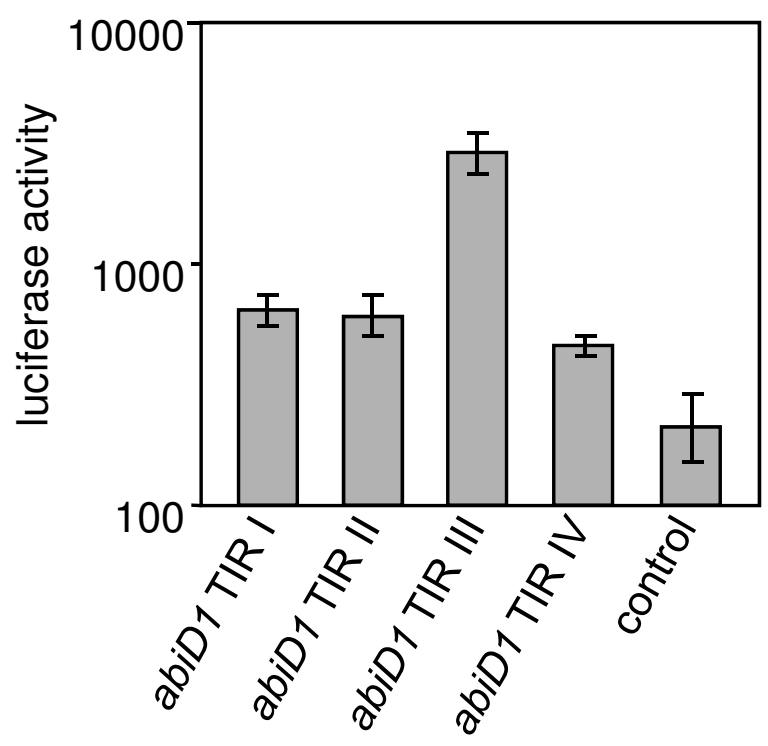

Figure 2

Translation of the abiDI mRNA. (A) MFOLD [44] predicted secondary structure of the abiD / translation initiation region (TIR). The sequence is presented from the transcriptional start $(+\mathrm{I})$ to the abiD I AUG start codon. Ribosome binding site (RBS) and the poly- $U$ stretch are boxed. Arrows show the $5^{\prime}$ ends of different TIRs used. The start of luxAB gene in fusion constructs is indicated. (B) Translation of abiD I TIR:luxAB fusions. The background level of luciferase activity was measured in the presence of plasmid pJIMI7I5 [50]. Experiments were performed at $30^{\circ} \mathrm{C}$. Results are means of 6-10 independent experiments. Luciferase activity is shown in arbitrary light units (lux/OD unit at an $O_{600}$ of $0.4)$. units (lux/OD unit at an OD of 0.4) [37], while abiD1 expression in the same context was $\sim 100$-fold lower. The difference observed between TIR III and TIR IV suggests a possible role of the poly-U sequence in increasing translation initiation, similar to what was described in E. coli [51]. Taken together, these results indicate that translation of abiD1 mRNA is inefficient and suggest that some transacting factor(s) might be required for its activation.

\section{Phage Orfl activates translation of abiD I mRNA}

In the search for putative factors activating translation of abiD1 mRNA we gave special attention to the phageencoded Orf1 protein, whose expression in mid-infection is essential for bIL66 abortive infection $[28,29]$. To explore the possibility that Orf1 protein acts as an activator of abiD1 expression, we studied the capacity of abiD1 TIR to direct lux $A B$ translation in the presence of Orf1. To keep a constant ratio between orf1 and abiD1 TIR in the different constructs, we cloned orf1 on plasmids carrying abiD1 TIR:luxAB translational fusions, so that orf1 and abiD1 TIR:luxAB were both transcribed from the same constitutive plasmid promoter. The fusion of $l u x A B$ reporter gene with TIR of $L$. lactis ald $B$ gene, preceded by a stable secondary structure that trapped the aldB RBS [52] was used as control. All plasmids were tested for luciferase activity in IL1403 cells. The presence of orf1 caused a 13to 27-fold increase in luciferase production, depending on the abiD1 TIRs (Fig. 3A). We replaced phage orf1 gene by mutated orf1 alleles M1 (A35D) or M2 (Q3*), coding for Orf1 protein with an amino acid substitution or deletion of the N-terminal part, respectively. Both mutations render bIL66 phage resistant to AbiD1 and differ from orf1 by one nucleotide [28]. Presence of mutated orf 1 genes abolished the increase of luciferase activity (Fig. 3A, TIRI and TIR II).

The level of luciferase activity directed by the control ald $B$ TIR:lux $A B$ fusion was not increased in the presence of the orf1 gene (Fig. 3A). These results indicate that orf1 specifically increases expression of abiD1. To measure the amount of the specific transcript, we analyzed $l u x A B$ mRNA using QRT-PCR. Similar amounts of $l u x A B$ RNA were detected in the presence and in the absence of either orf1 or orf1M1 gene for all tested constructs (Fig. 3B). These results indicate that the effect of orf1 on abiD1 TIR:luxAB fusions is not exerted on the transcriptional level.

We also performed Northern analysis of $\mathrm{Cm}$-stabilized abiD1 specific mRNA extracted from IL1403 AbiD1+ cells in the presence or absence of orf1-expressing plasmid pIL2002, which is known to increase AbiD1 activity [28]. As shown in Additional file 2 (Transcriptional analysis of 


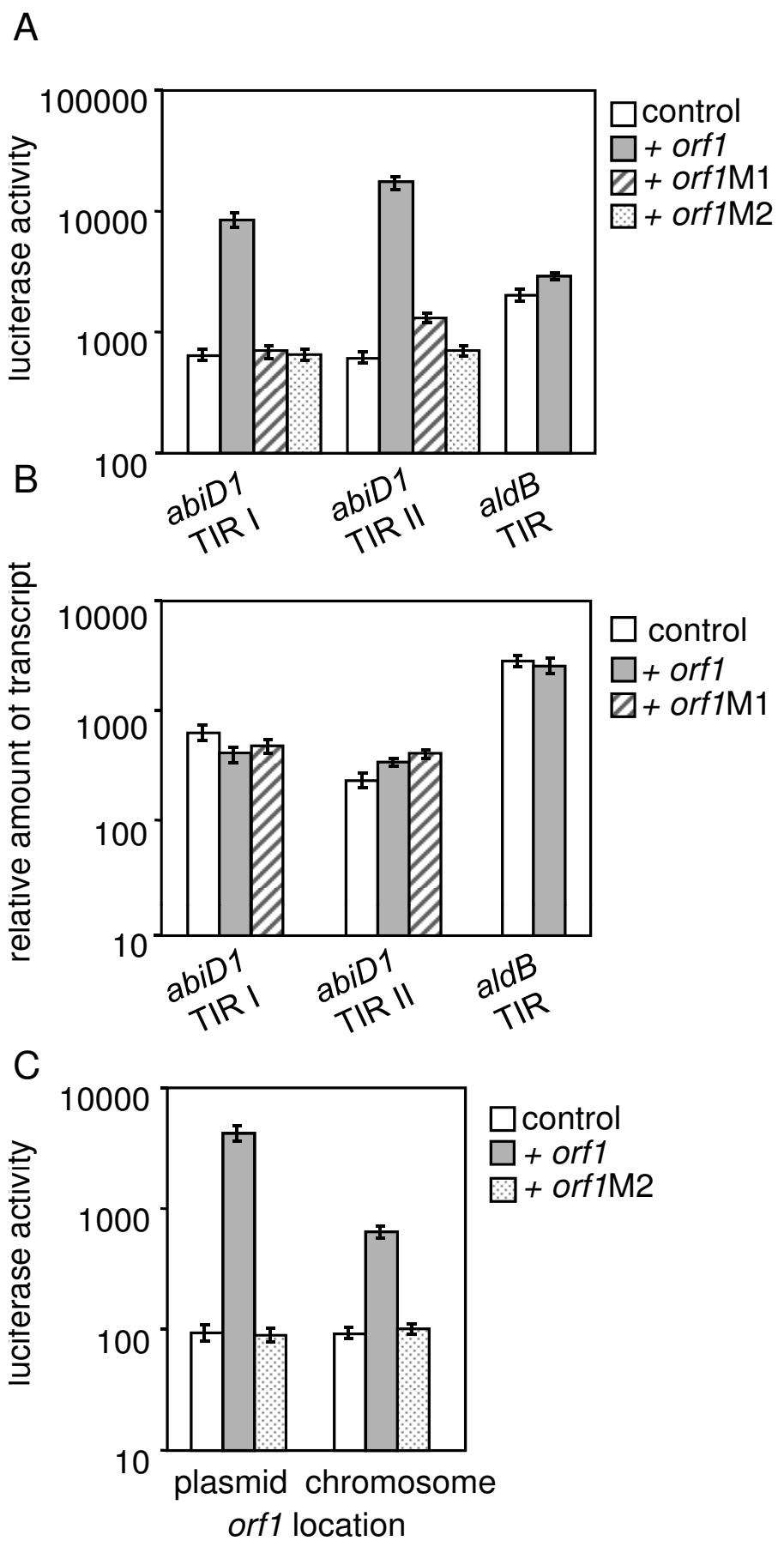

Figure 3

Orfl activates translation of abiDI TIR: luxAB fusions. (A) Translation of $a b i D /$ TIR I:luxAB, $a b i D /$ TIR II:IuxAB and aldB TIR:luxAB fusions in the absence (control) or in the presence of orfI, orfIMI and orfIM2 genes in L. lactis ILI403 cells. Experiments were performed at $30^{\circ} \mathrm{C}$. Results are means of 6 independent experiments. (B) Transcription of $a b i D / T I R: l u x A B$ fusions. The amount of $a b i D$ I TIR I: luxAB and $a b i D /$ TIR II: luxAB transcripts was measured by quantitative RT-PCR in the absence (control) and in the presence of orfl or orfIMI genes in L. lactis cells grown at $30^{\circ} \mathrm{C}$. The aldB TIR: luxAB fusion was used as a control. Amount of transcript was normalized to the $L$. lactis tuf transcript level. Values are means of $7-15$ measurements, expressed in arbitrary units. (C) Translation of abiD I TIR II:luxAB fusion in the presence of plasmid- or chromosome- integrated orfl and orfIM2 in B. subtilis 168 cells. Experiments were performed at $30^{\circ} \mathrm{C}$. Results are means of 4-5 independent experiments. Luciferase activity is shown in arbitrary light units (lux/OD unit at an $\mathrm{OD}_{600}$ of 0.4). 
the abiD1 in the presence of phage orf1 gene), the $3.6 \mathrm{~kb}$ transcript was detected in equal amounts in the presence or in the absence of Orf1 $\mathrm{w}^{+}$.

As transcription-translation reactions are known to be highly conserved among bacterial species [53], we used $B$. subtilis 168 cells to test orf 1 activity in trans. First we measured luciferase activity directed by plasmid constructs in the presence or absence of orf1 in cis. Luciferase activity directed by abiD1 TIRII:luxAB in B. subtilis cells was $45-$ fold higher in the presence of orf 1 compared to a control plasmid carrying abiD1 TIRII:luxAB without orf1. The orf1M2 did not increase translation of abiD1 TIR II:luxAB fusion (Fig. 3C). To test orf1 activity in trans, orf1 or its mutant orf1 M2 allele were placed under the control of inducible B. subtilis Pxyl promoter and integrated at the $a m y E$ locus of $B$. subtilis chromosome. Luciferase activity directed by abiD1 TIR II:luxAB fusion was measured at $30^{\circ} \mathrm{C}$ in the presence of $1 \%$ xylose. In these conditions, translation of abiD1 TIR II:luxAB fusion was activated approximately 7 -fold in the presence of orf 1 compared to the control. Activation was not observed with orf1 1 2 (Fig. 3C). Therefore, orf1 activates expression of abiD1 TIR:lux $A B$ fusion in trans and in cis in the heterologous $B$. subtilis host. Taken together, our results indicate that orf1 positively regulates translation of the abiD1 mRNA. The activation function of orf1 is most probably specific, as it was abolished by mutations rendering phage resistant to AbiD1, and it was not observed with control aldB TIR:luxAB fusion construct.

\section{Low temperature activates translation of abiDI mRNA and abortive infection phenotype}

The above results indicated that expression of abiD1 is activated by the infecting bIL66 phage. In a search for other potential extracellular induction signals, we measured the activity of $a b i D 1$ TIR I:luxAB fusion in different cell growth conditions. Various types of stress to which $L$. lactis is exposed during normal growth (acid $\mathrm{pH}$, oxidative stress, and low temperature) were tested. Among these, growth of IL1403 abiD1 TIR I:luxAB cells at the temperature range of $18^{\circ} \mathrm{C}$ to $20^{\circ} \mathrm{C}$ was found to increase luciferase activity about 15 -fold as compared to $30^{\circ} \mathrm{C}$ (Fig. $4 \mathrm{~A})$. This level of luciferase activity was reached after 2.5 hours incubation of IL1403 abiD1 TIR I:luxAB cells at $18^{\circ} \mathrm{C}$. However, we also detected a 3 -fold increase of the background luciferase level in cells carrying the control luxAB plasmid pJIM1715 at $18^{\circ} \mathrm{C}$, a phenomenon observed previously and attributed to more efficient folding of the LuxAB protein at low temperature [54-56]. Correcting for this increase, growth at $18^{\circ} \mathrm{C}$ conferred 5 -fold higher expression of $\operatorname{lux} A B$ when fused to the abiD1 TIR I region (Fig. 4A).
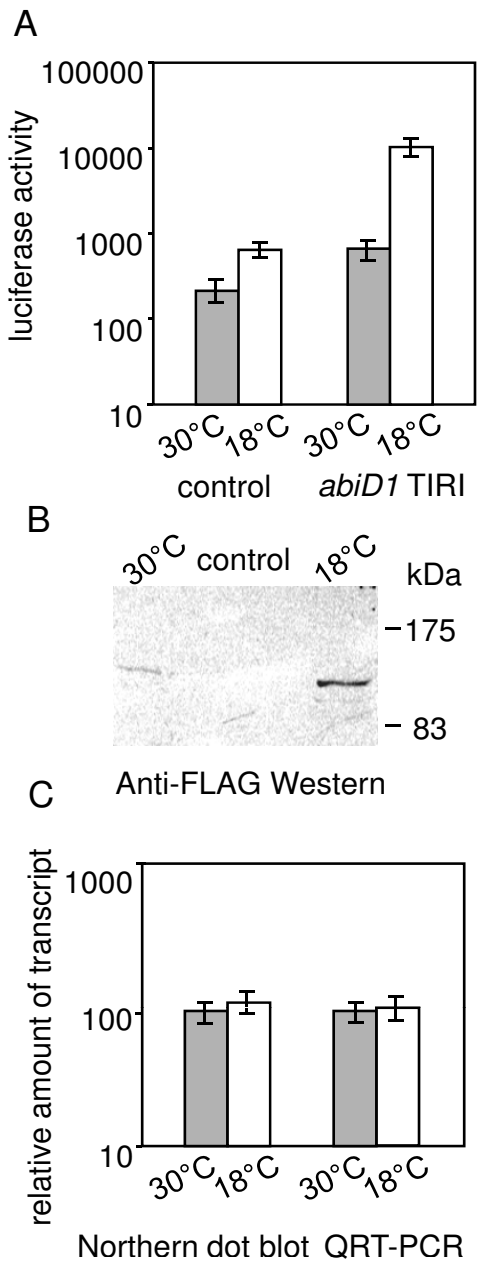

\section{Figure 4}

Effect of temperature on expression of the abiDI

TIRI : IuxAB fusion. (A) Translation of $a b i D /$ TIR I:luxAB fusion in L. lactis ILI 403 cells at $30^{\circ} \mathrm{C}$ and $18^{\circ} \mathrm{C}$. The background level of luciferase activity at $30^{\circ} \mathrm{C}$ and $18^{\circ} \mathrm{C}$ was measured in the presence of the control plasmid pJIMI7I5 [50]. Results are means of 5 independent experiments. Luciferase activity is shown in arbitrary light units (lux/OD unit at an $O D_{600}$ of 0.4 ). (B) Expression of FLAG-tagged LuxAB at $30^{\circ} \mathrm{C}$ and $18^{\circ} \mathrm{C}$. L. lactis cells carrying FLAG tagged abiD / TIR I:IuxAB fusion plasmid were grown to an $O_{600}$ of 0.4 at either $30^{\circ} \mathrm{C}$ or $18^{\circ} \mathrm{C}$ in $\mathrm{M} 17$ medium. Twenty $\mathrm{mg}$ of total cell protein were separated on an $8 \%$ SDS-PAGE gel. Western blot was developed with anti-FLAG tag M2 monoclonal antibody. The control panel shows cell lysates without specific FLAG-tagged protein. Molecular masses of standard proteins (Prestained Protein Marker, Broad Range, New England BioLabs) are indicated on the right. (C) Transcription of $a b i D$ I TIR:IuxAB fusion. The amount of $a b i D /$ TIR I: luxAB transcript in $L$. lactis cells grown at $30^{\circ} \mathrm{C}$ and $18^{\circ} \mathrm{C}$ was quantified by ImageQuant software after dot-blot Northern hybridization and by quantitative RT-PCR. Values are means of 3-7 measurements, expressed in arbitrary units. 
To confirm cold-induced activation of expression initiated by abiD1 TIR at the protein level we constructed in-frame fusions of $\operatorname{luxAB}$ with FLAG tag sequence on abiD1 TIR I:lux $A B$ plasmid pIL5014. abiD1 TIR I directed synthesis of tagged luciferase at $30^{\circ} \mathrm{C}$ and $18^{\circ} \mathrm{C}$ was analyzed by Western blotting with anti-FLAG antibodies. The amount of LuxAB-FLAG protein produced at $18^{\circ} \mathrm{C}$ was approximately 6-fold higher than at $30^{\circ} \mathrm{C}$ (Fig. 4B). Thus, the corrected level of specific luciferase activity detected at $18^{\circ} \mathrm{C}$ corresponds well to the increased level of protein synthesis at this temperature, and not to more efficient LuxAB folding. The amount of luxAB mRNA was measured by QRT-PCR and dot-blot Northern hybridization. Both methods revealed similar amounts of luxAB RNA in cells grown at $30^{\circ} \mathrm{C}$ and $18^{\circ} \mathrm{C}$ (Fig. $4 \mathrm{C}$ ). These results indicate that increase of luciferase activity of abiD1 TIR I:lux $A B$ fusion at $18^{\circ} \mathrm{C}$ is not due to activation of $\operatorname{lux} A B$ transcription. No additional increase of luciferase activity was observed in the presence of Orf1 at $18^{\circ} \mathrm{C}$ (data not shown). These results suggest that abiD1 expression is increased in L. lactis cells grown at $18^{\circ} \mathrm{C}$, and that induction occurs at the translational level.

These results led us to measure efficiency of phage abortive infection at $18^{\circ} \mathrm{C}$. Phage bIL66 and two AbiD1 ${ }^{\mathrm{R}}$ bIL66 mutants (bIL66 M1 and bIL66 M2) were plated on IL1403 and IL1403 AbiD1+ cells grown at $30^{\circ} \mathrm{C}$ and $18^{\circ} \mathrm{C}$ (Table 1). At $30^{\circ} \mathrm{C}$ phage bIL66 formed spontaneous AbiD1 ${ }^{\mathrm{R}}$ mutants at a frequency of $10^{-5}$ and the two bIL66 mutants grew normally. At $18^{\circ} \mathrm{C}$, in the presence of AbiD1, spontaneous AbiD1 ${ }^{\mathrm{R}}$ bIL66 mutants were not observed and growth of the two resistant mutants was strongly inhibited. In the absence of AbiD1, plaque-forming efficiency and plaque morphology of the wild type and mutant phages were similar at $18^{\circ} \mathrm{C}$ and at $30^{\circ} \mathrm{C}$. These results confirm that the AbiD1 phenotype is strongly activated during cell growth at low temperature independently of phage infection. Therefore, AbiD1 fits into the group of $L$. lactis cold shock-inducible proteins.

\section{L. lactis RbfA protein inhibits activation of AbiD I phenotype by low temperature, not by OrfI protein} Overproduction of cold shock protein RbfA was shown to accelerate growth adaptation of E. coli at low temperature and greatly decreases the adaptation period following cold shock [57-60]. The RbfA protein is conserved in most prokaryotic organisms [61].

To test whether high levels of RbfA protein weaken the AbiD1 phenotype activated either by phage encoded protein Orf1 or by low temperature we cloned the L. lactis $r b f A$ gene in high copy plasmid pGKV259 under the control of a strong constitutive promoter. The construct was introduced in the IL1403 AbiD1+ cells and abortive infection efficiency was determined at $30^{\circ} \mathrm{C}$ and $18^{\circ} \mathrm{C}$ (Table 2). RbfA had no effect on phage development at $30^{\circ} \mathrm{C}$. Interestingly, growth of the bIL66M 1 AbiD $1^{\mathrm{R}}$ phage on IL1403 AbiD1 + cells carrying the RbfA plasmid was as efficient at $18^{\circ} \mathrm{C}$ as at $30^{\circ} \mathrm{C}$. In the absence of RbfA, bIL66 $\mathrm{M} 1$ grew poorly at $18^{\circ} \mathrm{C}$ due to activation of abortive infection by low temperature (Table 2). This indicates that in the absence of active Orf1 protein synthesis of the AbiD1 protein was not induced by low temperature because of the presence of RbfA. In contrast, growth of wild type bIL66 phage was not detected at $18^{\circ} \mathrm{C}$ in the absence of $r b f A$ and was inefficient in the presence of $r b f A$, indicating that synthesis of AbiD1 is still activated in both strains by wild type Orf1 protein (Table 2). These results show that overproduction of RbfA (i) does not affect induction of AbiD1 abortive infection by the phage Orf1, intact in the wild-type phage, (ii) abolishes induction of AbiD1 abortive infection by low temperature, favouring the notion that abiD1 is a cold shock- regulated gene.

\section{Orfl binds abiD I mRNA}

Our study identified two AbiD1 activating signals, the phage-encoded protein Orf1 and low temperature, both acting at the level of mRNA translation. The Orf1 activation pathway differs from the cold shock pathway as it was

Table I: AbiD I abortive infection is activated at $18^{\circ} \mathrm{C}$

Phage titre ${ }^{a}(\mathrm{PFU} / \mathrm{ml})^{b}$

\begin{tabular}{|c|c|c|c|c|}
\hline \multirow{2}{*}{$\begin{array}{l}\text { Temperature: } \\
\text { Strain : }\end{array}$} & \multicolumn{2}{|c|}{$30^{\circ} \mathrm{C}$} & \multicolumn{2}{|c|}{$18^{\circ} \mathrm{C}$} \\
\hline & ILI 403 & ILI403 AbiDI+ & ILI 403 & ILI403 AbiDI+ \\
\hline \multicolumn{5}{|l|}{ Phage : } \\
\hline \multirow[t]{2}{*}{ bIL66 } & $3 \times 10^{10}$ & $2 \times 10^{5 c}$ & $2 \times 10^{10}$ & $<10^{2}$ \\
\hline & & $3 \times 10^{3} \mathrm{t}$ & & \\
\hline blL66.MI & $1 \times 10^{9}$ & $8 \times 10^{8}$ & $1 \times 10^{9}$ & $10^{2} \mathrm{t}$ \\
\hline blL66.M2 & $7 \times 10^{9}$ & $6 \times 10^{9}$ & $7 \times 10^{9}$ & $10^{2} \mathrm{t}$ \\
\hline
\end{tabular}

${ }^{a}$ Average of three independent experiments.

$b$ PFU: plaque forming units.

cclear plaques formed by spontaneous AbiDI resistant mutants.

$\mathrm{t}$, very small, turbid plaques. 
Table 2: L. lactis RbfA protein inhibits activation of AbiD I phenotype by low temperature

\begin{tabular}{|c|c|c|c|c|}
\hline \multirow[b]{2}{*}{ Temperature: } & & \multicolumn{3}{|c|}{ Phage titre $^{a}(\mathrm{PFU} / \mathrm{ml})^{b}$} \\
\hline & \multicolumn{2}{|c|}{$30^{\circ} \mathrm{C}$} & \multicolumn{2}{|c|}{$18^{\circ} \mathrm{C}$} \\
\hline & & \multicolumn{3}{|c|}{ ILI403 $\mathrm{AbiDI}^{+}$} \\
\hline Strain ${ }^{a}$ & - & $+r b f A$ & - & $+r b f A$ \\
\hline \multicolumn{5}{|l|}{ Phage : } \\
\hline \multirow[t]{2}{*}{ blL66 } & $8 \times 10^{4 c}$ & $2 \times 10^{5 c}$ & $<10^{2}$ & $3 \times 10^{3} \mathrm{t}$ \\
\hline & $2 \times 10^{3} \mathrm{t}$ & $3 \times 10^{3} \mathrm{t}$ & & \\
\hline bIL66.MI & $4 \times 10^{8}$ & $3 \times 10^{8}$ & $2 \times 10^{2} \mathrm{t}$ & $3 \times 10^{8}$ \\
\hline
\end{tabular}

${ }^{a}$ Average of three independent experiments.

b ILI403 $\mathrm{AbiDI}^{+}$strain carrying either pGKV259 vector (-) or pGKV259:rbfA (+ rbfA)

cclear plaques formed by spontaneous AbiDI resistant mutants.

$\mathrm{t}$, very small, turbid plaques.

shown not to be susceptible to RbfA-mediated cell adaptation to growth at low temperature. We supposed that Orf1 might activate translation of abiD1via binding to abiD1 mRNA.

To examine this hypothesis we tested whether Orf1 can specifically bind TIR of abiD1 mRNA. For this purpose, we performed a gel mobility shift assay using purified Orf1 protein and an abiD1 transcript that was synthesized in vitro with phage T7 RNA Polymerase. The transcript, designated mRNA 1, starts at the +1 transcription initiation point and is 297 nucleotides long (Fig. 5A). Incubation of mRNA 1 with increasing amounts of Orf1 protein followed by electrophoresis in non-denaturing polyacrylamide gel led to the appearance of bands with reduced mobility in the gel indicating the formation of RNA-protein complexes (Fig. 5B). The presence of several retarded bands reflects either formation of ribonucleoprotein complexes with different protein contents or different conformations of the same complex. The migration profile was not altered by increasing $\mathrm{KCl}$ concentrations, indicating that RNA-protein interactions are stable (data not shown).

To localize a binding region for Orf1, other transcripts were tested (Fig. 5A). mRNAs 2 and 3 start 35 and 53 bp downstream of +1 transcription initiation point respectively. mRNA 4 starts at the AUG of the abiD1-coding region, and thus lacks a translation initiation signal. mRNA 5 starts at the +1 transcription point and ends at the AUG of the abiD1 coding region. The mRNAs 6 and 7 correspond to the internal part of the abiD1 gene. Four transcripts (mRNAs 2, 3, 4 and 5) gave results similar to those obtained with mRNA 1 (data not shown). In con- trast, Orf1 did not bind transcripts 6 and 7(Fig. 5C). To control specificity of Orf1-RNA binding we used two other L. lactis transcripts:aldB and $\operatorname{trpA}$ mRNAs [52,62]. No binding to either RNA was detected (Fig. 5D). These results indicate that Orf1 specifically binds abiD1 TIR mRNA in the 5 '-region.

\section{Orfl might recognize a specific RNA motif}

To identify putative sequences or structural determinants involved in Orf1 interaction, we analyzed the mRNA transcript sequences used in binding experiments (abiD1 mRNAs 1 to 7 , aldB mRNA and $\operatorname{trpA}$ mRNA). Initial analyses using BLAST tools did not reveal any conserved sequence pattern in Orf1-binding transcripts. In contrast, FOLDALIGN, a method which detects common stemloop RNA motifs in unaligned sequences [63,64], revealed the presence of an mRNA stem-loop secondary structure in all abiD1 mRNAs shown to bind Orf1 (Fig. 6A). The secondary structures were cross-validated by MFOLD [45]. The putative RNA secondary structures are weak $\left(\Delta \mathrm{G}=-4.5\right.$ and $-6 \mathrm{Kcal} /$ mole at $\left.30^{\circ} \mathrm{C}\right)$, and are formed by AU-rich RNA ( $82 \%$ and $86 \%$ ), thus differing from stem-loop structure formed by L. lactis aldB TIR GCrich mRNA ( $\Delta \mathrm{G}=-15 \mathrm{Kcal} /$ mole; $45 \% \mathrm{AU})$. The structure present in abiD1 RNAs 1, 2, 3 and 4 is located upstream of the abiD1 ATG codon and sequesters abiD1 RBS. The second structure present in RNA 5 is located 152 nucleotides downstream of ATG codon. RNAs that were negative for Orf1 binding (abiD1 RNAs 6 and 7, and aldB and $\operatorname{trp} A$ mRNAs) were devoid of such RNA secondary structures.

We hypothesized that these structures could be involved in Orf1-RNA recognition. To verify this, we searched for other mRNAs containing similar structures and tested whether they can bind Orf1. First, we analyzed the sequence of the phage bIL66 mid-infection M-operon coding for Orf1. The orf1 gene is known to be involved in the regulation of expression of a phage structure-specific DNA endonuclease, encoded by the same operon $[28,29]$. The FOLDALIGN method revealed a putative AU-rich RNA secondary structure $(\Delta \mathrm{G}=-4.5 \mathrm{Kcal} / \mathrm{mole}$, Fig. $6 \mathrm{~B})$ within the M-operon mRNA, upstream of orf2 RBS, which initiates translation of the endonuclease [[29]; our unpublished results]. Moreover, no secondary structures like those above could be detected in 5'-untranslated sequences of two L. lactis genes coding for AbiD and AbiF abortive infection proteins, which share $28 \%$ to $46 \%$ of identity with AbiD1 protein, but are not regulated by Orf1 (GenBank accession numbers AAA63619 and ABG00298 respectively, our unpublished results). We also looked at known L. lactis cold-shock inducible genes, pgmB, osmC, $l l r C$, hslA and $c l p X[65,66]$. Interestingly, FOLDALIGN revealed possible structures similar to those described above, upstream of putative RBS motifs of each of these genes (Fig. 6B). In contrast, no such structures were found 


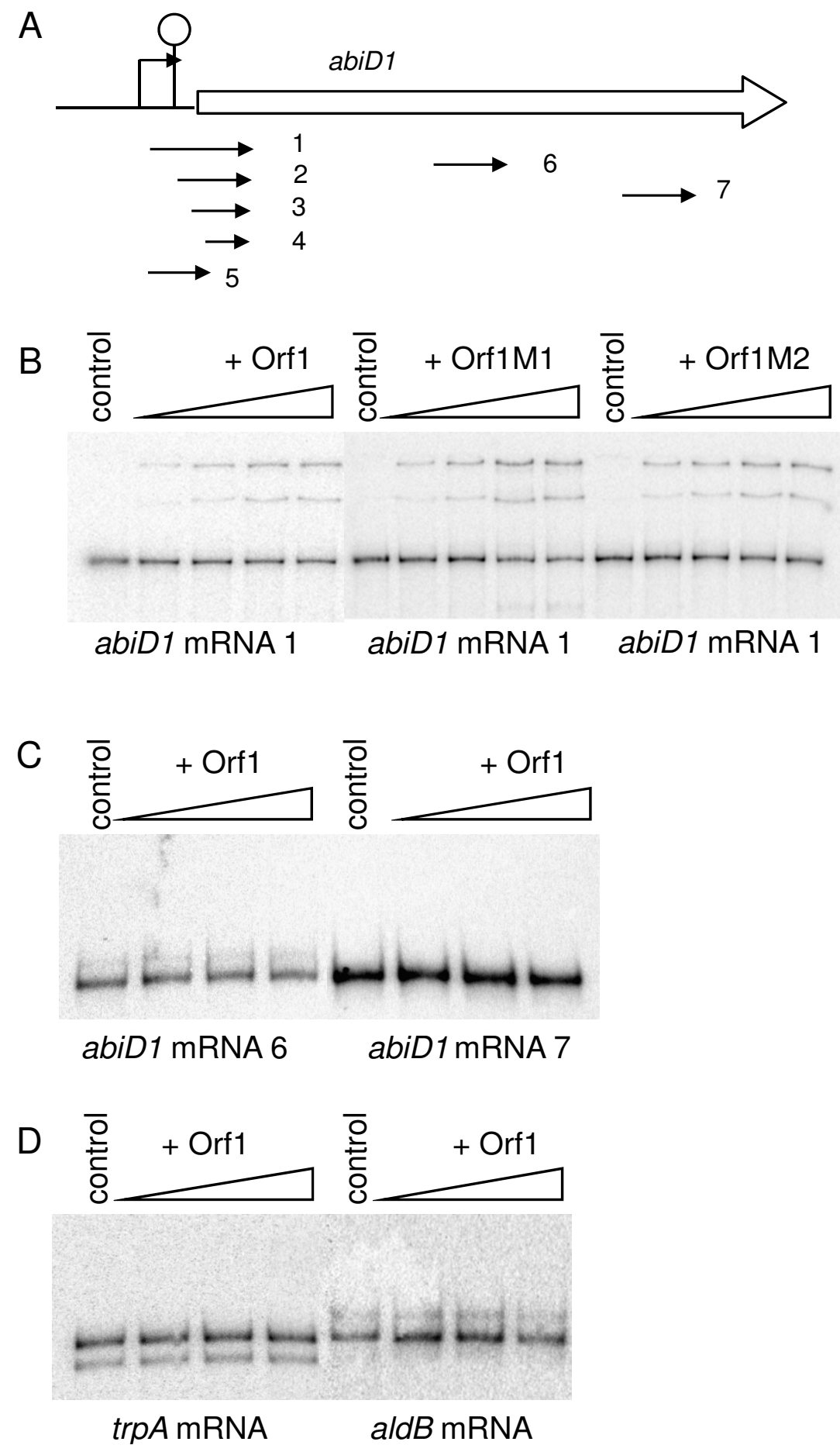

\section{Figure 5}

Orf I-RNA binding activity. (A) Schematic organization of the abiD / gene. Arrows indicate position of abiD / transcripts (I to 7) used for binding experiments. (B) Binding of purified Orfl, OrfMI and OrfIM2 to the abiDI mRNA I. Ten ng of radiolabelled abiD I mRNA (transcript I) were incubated with increasing amounts of OrfI, OrfMI or OrfM2 protein (0; $0.03 \mu$ M; 0.05 $\mu \mathrm{M} ; 0.1 \mathrm{I} \mu \mathrm{M} ; 0.22 \mu \mathrm{M}$ ), followed by separation of the nucleoprotein complex in an $8 \%$ non-denaturing polyacrylamide gel at room temperature. (C) Binding of Orfl to the abiD I mRNA 6 and abiD I mRNA 7. (D) Binding of Orfl to trpA mRNA and aldB mRNA. Experiments $(C$ and $D)$ were performed with increasing amounts of Orfl protein $(0 ; 0.11 \mu \mathrm{M} ; 0.22 \mu \mathrm{M} ; 0.33 \mu \mathrm{M})$ in the same conditions as above. 
A

\section{abiD11 abiD12}

\begin{tabular}{|c|c|c|}
\hline U & U & $U \quad U$ \\
\hline A & U & C \\
\hline$C=G$ & & $C=G$ \\
\hline$U-A$ & & $U-A$ \\
\hline A & A & $U-A$ \\
\hline$U-A$ & & A \\
\hline$U \cdot G$ & & $U-A$ \\
\hline$U \cdot G$ & & $U-A$ \\
\hline$U-A$ & & \\
\hline$U-A$ & & $U-A$ \\
\hline$U-A$ & & $U-A$ \\
\hline$U-A$ & & $U-A$ \\
\hline
\end{tabular}

B

M-operon osmC hslA clpX IIrC pgmB

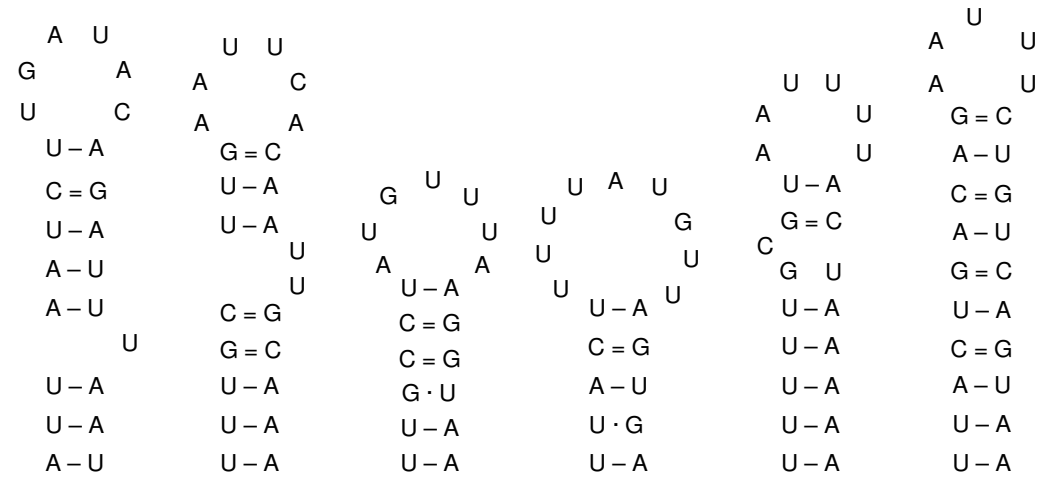

C

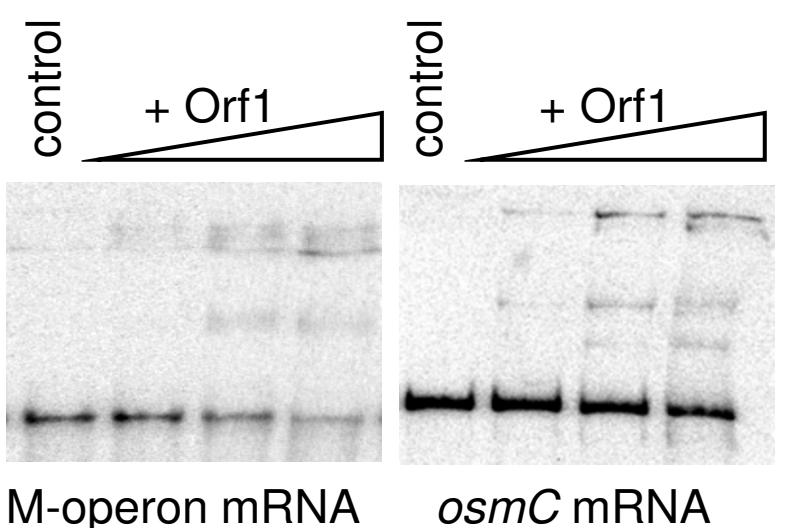

\section{Figure 6}

Putative Orfl-binding mRNA motif. (A) Predicted mRNA secondary structures reveled by FOLDALIGN [67,68] in $a b i D I$ mRNA (nucleotide positions are 734I-7362; 75 I8-7539; GenBank Accession Number AFI 16286) and (B) phage bll66 midinfection induced M-operon mRNA (nucleotide positions are 566-59I; GenBank Accession Number L35I75) and L. lactis IL I 403 cold shock inducible genes osmC, hsIA, clpX, IIrC and pgmB mRNAs (nucleotide positions are 68675-68698; 502344502363; I I63846-I 163866; 403740-403763 and 442024-442049, respectively; GenBank Accession Number NC 002662). Gene names are indicated. (C) Binding of Orfl to M-operon and osmC RNAs. Experiments were performed with increasing amounts of Orfl $(0 ; 0.05 \mu \mathrm{M} ; 0.11 \mu \mathrm{M} ; 0.22 \mu \mathrm{M})$ in the same conditions as above. 
in the intragenic regions of $L$. lactis IL1403 biosynthetic trp and his operons, which are known not to be regulated by low temperature (GenBank accession number NC_002662).

Next, we tested the capacity of Orf1 to bind two mRNAs containing the identified RNA motif: phage M-operon and L. lactis osmC. Transcripts were synthesized in vitro using phage T7 RNA Polymerase. M-operon transcript started at the +1 transcription initiation point, was 225 nucleotides long, and included the RBS and the putative stem-loop structure.L. lactis osmC transcript started 130 nucleotides upstream of the ATG codon, was 190 nucleotides long, and included the RBS and the putative stemloop structure. Orf1 was able to bind both osm C mRNA and M-operon mRNA (Fig. 6C). Taken together, our results suggest that Orf1 most probably binds mRNA via recognition of specific secondary structure motif.

\section{OrfI binding alone does not account for abiD I translation activation}

To test whether Orf1 binding to the abiD1 mRNA is sufficient to activate AbiD1, we purified the two mutant proteins, Orf1M1 and Orf1M2, encoded by AbiD1 resistant phages bIL66M1 and bIL66M2. Although these proteins are unable to activate abiD1 translation, they were found to bind abiD1 mRNAs 1, 2, 3, 4 and 5 in the same manner as wild-type Orf1 (Fig. 5B, data shown for mRNA 1) and not RNAs 6 and 7 (data not shown). These results indicate that activation of abiD1 translation is not due exclusively to Orf1 binding, even if it seems likely that binding plays a role in activation.

\section{Discussion}

Expression of the lactococcal phage abortive infection mechanism AbiD1 is repressed under normal growth conditions and activated following phage infection and during cell growth at low temperature. Phage Orf1 protein and cold shock are shown here to activate expression of the abiD1 gene at the level of mRNA translation.

Expression of $a b i D 1$ is tightly controlled. Transcription of $a b i D 1$ is weak, and abiD1 mRNA is unstable and poorly translated. A putative mRNA stem-loop structure in the abiD1 TIR might sequester both the abiD1 RBS and an upstream poly-U sequence. Using translational fusions of $a b i D 1$ TIRs with luxAB gene, we showed that this structure had a negative effect on luciferase synthesis. However, even with a free access to the abiD1 RBS, translation initiation was inefficient. These data suggest that abiD1 full expression might depend on activation. Here we show that the phage bIL66 orf1 gene, which is responsible for its sensitivity to AbiD1, activates abiD1 translation. In contrast, the orf 1 genes from $\mathrm{AbiD} 1^{\mathrm{R}}$ mutants do not activate translation. This positive regulation of the AbiD1 phage abortive mechanism is somewhat similar to activation of the E. coli exclusion systems Lit and Prr by phage T4 encoded proteins Gol and Stp, respectively, as mutations in the corresponding phage genes abolish activation [11]. Thus, activation of latent Abi mechanisms by phage proteins synthesized during infection seems to be a feature common to different mechanisms. Our study describes the first example of a mechanism in which Abi activation takes place at the level of translation.

Examples of protein-mediated positive regulation of translation, like that described in this paper, are very rare. Those studied are mediated by modification of local mRNA structure, thereby facilitating ribosome access to RBS, or by modification of some components of the cellular transcription-translation apparatus with consequent change in translation of some specific mRNAs [67-69]. Post-transcriptional mechanisms were shown to play a major role in adaptation of vegetative $E$. coli cells to the cold. Preferential translation of cold shock-induced genes at low temperatures is due to cis-elements found in the $5^{\prime}$ untranslated region of at least some mRNAs and trans-acting factors $[70,71]$. Activation of the abiD1 translation and the consequent abortive infection phenotype by a temperature decrease of $10^{\circ} \mathrm{C}-12^{\circ} \mathrm{C}$ is of immediate interest, as such a temperature drop was shown to induce a cold-shock response $[72,73]$. It therefore appears that AbiD1 is a cold shock-inducible protein. This conclusion is supported by the observation that overproduction of the ribosome binding factor RbfA, which is essential for ribosomal adaptation to the cold, prevents induction of abiD1 by low temperature.

The detailed mechanism of Orf1 action remains to be established. Binding to a structure found in the 5'untranslated regions of abiD1 and phage M-operon mRNAs could be involved. Nevertheless, the mutant proteins that were unable to activate AbiD1 translation, do bind the motif with comparable efficiency, which indicates that binding alone is not sufficient for activation. We propose that in the course of phage infection Orf1 binds to abiD1 mRNA and acts as a "platform" that interacts with additional factors involved in mRNA translation. In this case, mutations would alter the interaction. Similar mechanism was proposed for $E$. coli Hfq protein involving in regulation of translation of $r p o S$ gene [74]. Identification of the cellular partner(s) of Orf1 protein should clarify our understanding of Orf1-mediated translational activation of abiD1 expression, and the role of the orf1 gene in phage development.

\section{Conclusion}

We studied expression of the abiD1 gene at the transcriptional and post-transcriptional level. Expression of abiD1 is specifically activated at the level of mRNA translation by 
the phage-encoded Orf1 protein. The loss of ability to activate translation of abiD1 mRNA determines the molecular basis for phage resistance to AbiD1. Identification of temperature decrease as an environmental signal activating AbiD1 phenotype indicates that the abiD1 is a cold shock inducible gene.

\section{Authors' contributions}

EB conceived and performed the experiments, analyzed the data and drafted the manuscript; AC performed the QRT PCR analysis, participated in Orf1-RNA binding experiments and in revising the manuscript; MCC and SDE participated in the analysis of data and helped draft the manuscript; all authors read and approved the manuscript.

\section{Additional material}

\section{Additional File 1}

Oligonucleotides used in this study. This table contains a list of the oligonucleotides used in the study.

Click here for file

[http://www.biomedcentral.com/content/supplementary/14712199-10-4-S1.pdf]

\section{Additional File 2}

Transcriptonal analysis of the abiD1 gene. This file provides results of Northern hybridization analysis of the abiD1 gene region in the presence and in the absence of the orf1 gene. A) Schematic organization of the abiD1 gene region. Bent arrows and circles denote promoter and terminator sequences, respectively. Position of the oligonucleotide used as probe for Northern hybridization is indicated by tail-less arrow. Transcripts initiated at the abiD1 promoter are shown by solid (50 b) and broken (3.6 $k b)$ lines. B) Northern hybridization results. RNA was extracted from IL1403 AbiD1+, pIL2002 [28] and IL1403 AbiD1+, pIL253 cells grown with Cm. Hybridization was performed with oligonucleotide $n^{\circ} 1$ as probe. Click here for file

[http://www.biomedcentral.com/content/supplementary/14712199-10-4-S2.pdf]

\section{Acknowledgements}

We thank P. Mervelet for sequencing of pILI05 plasmid, and P. Polard and S. McGovern for helpful suggestions during Orfl purification and RNAbinding experiments. We are grateful to $A$. Gruss for critical reading of the manuscript.

\section{References}

I. Smith HS, Pizer LI, Pylkas L, Lederberg S: Abortive infection of Shigella dysenteriae P2 by T2 bacteriophage. J Virol 1969 , 4:162-168.

2. Rettenmier CW, Hemphill E: Abortive infection of lysogenic Bacillus subtilis 168 (SP02) by bacteriophage I. J Virol 1974, 13:870-880.

3. Behnke D, Malke H: Bacteriophage interference in Streptococcus pyogenes. I. Characterization of prophage-host systems interfering with the virulent phage A25. Virology 1978, 85: $118-128$.
4. Biswas S, Chowdhury R, Das I: A I4-Kilodalton inner membrane protein of Vibrio cholerae biotype EI Tor confers resistance to group IV choleraphage infection to classical vibrios. J Bacteriol I992, I 74:622I-6229.

5. Tran L-SP, Szabo L, Ponyi T, Orosz L, Sik T, Holczinger A: Phage abortive infection of Bacillus licheniformis ATCC 9800; identification of the $a b i B L I /$ gene and localisation and sequencing of its promoter. Appl Microbiol Biotechnol 1999, 52:845-852.

6. Molineux IJ: Host-parasite interactions: recent developments in the genetics of abortive phage infections. New Biol 1991, 3:230-236.

7. Snyder L: Phage-exclusion enzymes: a bonanza of biochemical and cell biology reagents? Mol Microbiol 1995, 15:415-423.

8. Coffey A, RP Ross: Bacteriophage -resistance systems in dairy starter strains: molecular analysis to application. Antonie Van Leeuwenhoek 2002, 82:303-321.

9. Daly C, Fitzgerald GF, Davis R: Biotechnology of lactic acid bacteria with special reference to bacteriophage resistance. Antonie Van Leeuwenhoek 1996, 70:99-II 0.

10. Snyder L, Kaufmann G: Molecular biology of bacteriophage T4 Edited by: Karam JD. ASM, Washington, DC; 1994:391-396.

II. Schmitt CK, Kemp P, Molineux IJ: Genes 1.2 and 10 of bacteriophages T3 and T7 determine the permeability lesions observed in infected cells of Escherichia coli expressing the $F$ plasmid gene pifA. J Bacteriol |99|, |73:6507-65|4.

12. Cheng $X$, Wang WF, Molineux II: $F$ exclusion of bacteriophage T7 occurs at the cell membrane. Virology 2004, 326:340-352.

13. Parma DH, Snyder M, Sobolevski S, Nawroz M, Brody E, Gold L: The Rex system of bacteriophage : tolerance and altruistic cell death. Genes Dev 1992, 6:497-510.

14. Kaufmann G, David M, Borasio GD, Teichmann A, Paz A, Green R, Snyder L: Phage and host genetic determinants of the specific anticodon-loop cleavages in bacteriophage T4 infected Escherichia coli CTr5X. J Mol Biol I986, I 88:15-22.

15. Penner M, Morad I, Snyder L, Kaufmann G: Phage T4-coded Stp: double-edged effector of coupled DNA and tRNA-restriction systems. I Mol Biol 1995, 249:857-868.

16. Amitsur M, Benjamin S, Rosne R, Chapman-Shimshoni D, Meidler R, Blanga S, Kaufmann G: Bacteriophage T4-encoded Stp can be replaced as activator of anticodon nuclease by a normal host cell metabolite. Mol Microbiol 2003, 50:129-143.

17. Copeland NA, Kleanthous C: The role of an activating peptide in protease-mediated suicide of Escherichia coli-KI2. J Biol Chem 2004, 280: I I2-II7.

18. Engelberg-Kulka $H$, Reches M, Narasimhan S, Schoulaker-Schwarz R, Klemes $Y$, Aizenman E, Glazer G: rexB of bacteriophage is an anti-cell death gene. Proc Natl Acad Sci USA 1998, 95: I 548 I-I 5486.

19. Slavcev RA, Hayes S: Stationary phase-like properties of the bacteriophage Rex exclusion phenotype. Mol Gen Genomics 2003, 269:40-48.

20. Chopin M-C, Chopin A, Bidnenko E: Phage abortive infection in lactococci: variations on a theme. Curr Opinion Microbiol 2005, 8:473-479.

21. Yang JM, DeUrraza PJ, Matvienko N, O'Sillivan DJ: Involvement of the LlaKR2I methylase in expression of the AbiR bacteriophage defense system in Lactococcus lactis subsp. lactis biovar diacetylactis. J Bacteriol 2006, I88:1920-1928.

22. Durmaz E, Klaenhammer TR: Abortive phage resistance mechanism AbiZ speeds the lysis clock to cause premature lysis of phage-infected Lactococcus lactis. J Bacteriol 2007, 189: 1417-1425

23. Hill C, Miller LA, Klaenhammer TR: Nucleotide sequence and distribution of the PTR2030 resistance determinant (hsp) which aborts bacteriophage infection in lactococci. Appl Environ Microbiol 1990, 56:2255-2258.

24. Anba J, Bidnenko E, Hiller A, Ehrlich SD, Chopin M-C: Characterization of the lactococcal abiDI gene coding for phage abortive infection. J Bacteriol 1995, I77:3818-3823.

25. O'Connor L, Tangney M, Fitzgerald GF: Expression, regulation and mode of action of the AbiG abortive infection system of Lactococcus lactis subsp. cremoris UC653. Appl Environ Microbiol 1999, 65:330-335.

26. Domingues S, Chopin A, Ehrlich SD, Chopin M-C: The lactococcal abortive phage infection system AbiP prevents both phage 
DNA replication and temporal transcription switch. J Bacteriol 2004, I86:7I3-72I.

27. Gautier M, Chopin M-C: Plasmid-determined systems for restriction and modification activity and abortive infection in Streptococcus cremoris. Appl Environ Microbiol 1987, 53:923-927.

28. Bidnenko E, Ehrlich SD, Chopin M-C, Anba J: Lactococcus lactis AbiD I abortive infection efficiency is drastically increased by a phage protein. FEMS Microbiol Lett 2002, 21 4:283-287.

29. Bidnenko E, Ehrlich SD, Chopin M-C: Phage operon involved in sensitivity to the Lactococcus lactis abortive infection mechanism AbiD I. J Bacteriol 1995, 177:3824-3829.

30. Bidnenko E, Ehrlich SD, Chopin M-C: Lactococcus lactis phage operon coding for an endonuclease homologous to RuvC. Mol Microbiol 1998, 28:823-834.

31. Charples G]: The $\mathbf{X}$ philes: structure-specific endonuclease that resolve Holliday junctions. Mol Microbiol 200I, 39:823-834.

32. Curtis F, Reed P, Sharples G]: Evolution of a phage RuvC endonuclease for resolution of both Holliday and branched DNA junctions. Mol Microbiol 2004, 55: I332-1345.

33. Sambrook J, Fritsch EF, Maniatis T: Molecular cloning: A Laboratory Manual 2nd edition. Cold Spring Harbor Laboratory Press, Cold Spring Harbor NY; 1989.

34. Holo H, Nes IF: High-frequency transformation, by electroporation, of Lactococcus lactis subsp. cremoris grown with glycine in osmotically stabilized media. Appl Environ Microbiol I989, 55:31| 9-3। 23.

35. Gibson UE, Heid CA, Williams PM: A novel method for real time quantitative RT-PCR. Genome Res 1996, 6:995-I00I.

36. Heid CA, Stevens J, Livak KJ, Williams PM: Real time quantitative PCR. Genome Res 1996, 6:986-994.

37. Renault P, Corthier G, Goupil N, Delorme C, Ehrlich SD: Plasmid vectors for Gram-positive bacteria switching from high to low copy number. Gene 1996, 183:175-182.

38. Bhavsar AP, Zhao X, Brown ED: Development and characterization of a xylose-dependent system for expression of cloned genes in Bacillus subtilis: conditional complementation of a teichoic acid mutant. Appl Environ Microbiol 200I, 67:403-4I0.

39. Vossen JMBM Van der, Lelie D, Venema G: Isolation and characterization of Streptococcus cremoris Wg2-specific promoters. Appl Environ Microbiol 1987, 53:2452-2457.

40. Rallu F, Gruss A, Maguin E: Lactococcus lactis and stress. Antonie Van Leeuwenhoek 1996, 70:243-25I.

4I. Rallu F, Gruss A, Ehrlich SD, Maguin E: Acid- and multistressresistant mutants of Lactococcus lactis: identification of intracellular stress signals. Mol Microbiol 2000, 35:5|7-528.

42. Lopez PJ, Marchand I, Yarchik O, Dreyfus M: Translation inhibitors stabilize Escherichia coli mRNAs independently of ribosome protection. Proc Natl Sci USA 1998, 95:6067-6072.

43. Chandry PS, Davidson BE, Hiller AJ: Temporal transcription map of the Lactococcus lactis bacteriophage sk I. Microbiology 1994 | 40(Pt 9):225|-226I.

44. Chiaruttini $C$, Milet M: Gene organization, primary structure and RNA processing analysis of a ribosomal RNA operon in Lactococcus lactis. J Mol Biol 1993, 230:57-76.

45. Zuker M: Mfold web server for nucleic acid folding and hybridization prediction. Nucl Acids Res 2003, 31:3406-34I5.

46. Zhang J, Deutscher MP: A uridine-rich sequence required for translation of prokaryotic mRNA. Proc Natl Acad Sci USA 1992 89:2605-2609.

47. Hofacker IL: Vienna RNA secondary structure server. Nucleic Acids Res 2003, 31:3429-3431.

48. Evers D, Giegerich R: RNA Movies: visualizing RNA secondary structure spaces. Bioinformatics 1999, 15:32-37.

49. De Rijk P, De Wachter R: RnaViz, a program for the visualisation of RNA secondary structure. Nucleic Acids Res 1997, 25:4679-4684

50. Eaton TJ, Shearman CA, Gasson MJ: The use of bacterial luciferase genes as reporter genes in Lactococcus: regulation of the Lactococcus lactis subsp.lactis lactose genes. J Gen Microbiol 1993, 139:1495-1501.

5I. Sorensen MA, Fricke J, Pedersen S: Ribosomal protein SI is required for translation of most, if not all, natural mRNAs in Escherichia coli in vivo. I Mol Biol 1998, 280:56I-569.

52. Goupil-Feuillerat N, Corthier G, Godon JJ, Ehrlich SD, Renault P: Transcriptional and translational regulation of a-acetolac- tate decarboxylase of Lactococcus lactis subsp. lactis. J Bacteriol 2000, 182:5399-5408.

53. Ganoza MC, Kiel M, Aoki H: Evolutionary conservation of reactions in translation. Microbiol Mol Biol Rev 2002, 66:460-485.

54. Escher A, O'Kane DJ, Lee J, Szalay AA: Bacterial luciferase fusion protein is fully active as a monomer and highly sensitive in vivo to elevated temperature. Proc Natl Acad Sci USA 1989, 86:6528-6532.

55. O'Connell KP, Gustafson AM, Lehmann MD, Thomashow MF: Identification of cold shock gene loci in Sinorhizobium meliloti by using a luxAB reporter transposon. Appl Environ Microbiol 2000, 66:40I-405

56. Gustafson AM, O'Connell K, Thomashow MF: Regulation of Sinorhizobium meliloti 1021 rrnA-reporter gene fusions in response to cold shock. Can J Microbiol 2002, 48:82I-830.

57. Bylund GO, Wipemo LC, Lundberg LA, Wikstrom PM: RimM and RbfA are essential for efficient processing of 16 S rRNA in Eschirichia coli. J Bacteriol 1998, 180:73-82.

58. Inouye M, Alsina J, Chen J, Inouye M: Suppression of defective ribosome assembly in a rbfA deletion mutant by overexpression of Era, an essential GTPase in Escherichia coli. Mol Microbiol 2003, 48: 1005-1016.

59. Xia $\mathrm{B}, \mathrm{Ke} \mathrm{H}$, Shinde $U$, Inouye $\mathrm{M}$ : The role of RbfA in $16 \mathrm{~S}$ rRNA processing and cell growth at low temperature in Escherichia coli. J Mol Biol 2003, 332:575-584

60. Jones PG, Inouye M: RbfA, A 30 S ribosomal binding factor, is a cold-shock protein whose absence triggers the cold-shock response. Mol Microbiol 1996, 21:1207-1218.

6I. Dammel CS, Noller HF: Suppression of a cold-sensitive mutation in I6S rRNA by overexpression of a novel ribosomebinding factor, RbfA. Genes Dev 1995, 9:626-637.

62. Bardowski J, Ehrlich SD, Chopin A: Tryptophan biosynthesis genes in Lactococcus lactis subsp. lactis. J Bacteriol 1992, 174:6563-6570.

63. Havgaard JH, Lyngsø RB, Gorodkin J: The FOLDALIGNE web server for pairwise structural RNA alignment and mutual motif search. Nucleic Acids Res 2005, 33:650-653.

64. Havgaard JH, Lyngsø RB, Stormo GD, Gorodkin J: Pairwise local structural alignment of RNA sequences with sequence similarity less than 40\%. Bioinformatics 2005, 21:1815-1824.

65. Skinner MM, Trempy JE: Expression of clpX, an ATPase subunit of the Clp protease, is heat and cold shock inducible in Lactococcus lactis. J Dairy Sci 2000, 84(8): I783-I785.

66. Wouters JA, Frenkiel H, de Vos WM, Kuipers OP, Abee T: Cold shock proteins of Lactococcus lactis MGI363 are involved in cryoprotection and in the production of cold-induced proteins. Appl Enviroment Microbiol 200I, 67:5I7I-5I78.

67. Hattman S, Newman L, Murthy HMK, Nagaraja V: Com, the phage Mu mom translational activator, is a zing-binding protein that binds specifically to its cognate mRNA. Proc Natl Acad Sci USA 199|, 88: |0027-I003I.

68. Springer M: Translational control of gene expression in E. coli and bacteriophage. In Regulation of gene expression in Escherichia coli Edited by: Lin ECC, Simon Lynch A. Landes Com; 1996:85-I 26.

69. Romby P, Springer M: Bacterial translational control at atomic resolution. Trends Genet 2003, 3:|55-6I.

70. Ermolenko DN, Makhatadze Gl: Bacterial cold-shock proteins. Cell Mol Life Sci 2002, 59:1902-1913.

71. Giuliodori AM, Brandi A, Gualerzi CO, Pon CL: Preferential translation of cold-shock mRNA during cold adaptation. RNA 2004, 10:265-276.

72. Thieringer HA, Jones PG, Inouye M: Cold shock and adaptation. BioEssays 1998, 20:49-57.

73. Budde I, Steil L, Scharf C, Völker U, Bremer E: Adaptation of Bacillussubtilis to growth at low temperature: a combined transcriptomic and proteomic appraisal. Microbiology 2006, I52:83|-853.

74. Hengge-Aronis R: Signal transduction and regulatory mechanisms involved in control of the $\mathbf{S}$ (RpoS) subunit of RNA polymerase. Microbiol Mol Biol Rev 2002, 66:373-395. 